\title{
PSIKOEDUKASI MENGOPTIMALKAN KECERDASAN EMOSI DAN SPIRITUAL ANAK SEJAK DINI
}

\author{
Khairul Amri ${ }^{1)}$; Nor Mita Ika Saputri ${ }^{2)}$; Sukatno ${ }^{3)}$; Abubakar $^{4)}$ \\ ${ }^{1,2,3)}$ Bimbingan dan Konseling, FKIP Universitas Muhammadiyah Tapanuli Selatan \\ ${ }^{4)}$ Pendidikan Kimia, FKIP Universitas Muhammadiyah Tapanuli Selatan \\ normita.ika@um-tapsel.ac.id
}

\begin{abstract}
Psychoeducation is a counselling on how to optimize the emotional intelligence and spiritual intelligence of children from an early age. This devotion is done for two months from January to February 2017. This dedication will be useful for teachers to develop children's intelligence optimally. Thus, teachers focus not only on the values of intellectual intelligence but also on other intelligence that will support the success of children later, such as emotional and spiritual intelligence. The results of this psychoeducation activity are: (1) the target of the previously planned trainees is at least 50 people, and the attendance is 100 people. Thus the target of the trainees can be said successful; (2) the teacher canrecognize and develop the child's emotional and spiritual intelligence through his body language; (3) the material delivered also has reached the target. The material presented includes: (a) recognizing the emotions of the child, (b) releasing negative emotions, (c) managing oneself emotions, (d) motivating oneself, (e) recognizing the emotions of others, (f) motivating others, (g) fostering relationships, (h) recognize the personality and emotions of the child, (i) adopt a parenting pattern appropriate to the child's development and personality, (j) communicate well with the child, (k) discuss all issues together, (l) tell grand stories, (m) involve the child in religious rituals.
\end{abstract}

Keywords: Psychoeducation, emotional intelligence, spiritual intelligence

\begin{abstract}
Abstrak
Psikoedukasi ini berupa penyuluhan tentang cara mengoptimalkan kecerdasan emosional dan kecerdasan spiritual anak sejak dini. Pengabdian ini dilakukan selama dua bulan mulai januari sampai februari 2017. Pengabdian ini akan bermanfaat bagi para guru untuk mengembangkan kecerdasan anak secara optimal. Sehingga, guru tidak hanya fokus pada nilai-nilai kecerdasan intelektual, tetapi juga pada kecerdasan lain yang akan mendukung keberhasilan anak nantinya, seperti kecerdasan emosional dan spiritual. Hasil kegiatan psikoedukasi ini adalah: (1) target peserta latihan direncanakan sebelumnya adalah minimal 50 orang, dan jumlah peserta yang hadir adalah 100 orang. Dengan demikian target peserta pelatihan dapat dikatakan sukses/berhasil; (2) guru mampu mengenal dan mengembangkan kecerdasan emosi dan spiritual anak melalui bahasa tubuhnya; (3) materi yang disampaikan juga sudah mencapai target. Materi yang disampaikan mencakup: (a) mengenal emosi anak, (b) melepaskan emosi negatif, (c) mengelola emosi diri sendiri, (d) memotivasi diri sendiri, (e) mengenali emosi orang lain, (f) memotivasi orang lain, (g) membina hubungan, (h) mengenali kepribadian, dan emosi anak, (i) menerapkan pola asuh yang sesuai dengan perkembangan dan kepribadian anak, (j) berkomunikasi yang baik dengan anak, (k) mendiskusikan segala persoalan bersama-sama, (l) menceritakan kisah-kisah yang agung, (m) melibatkan anak dalam ritual keagamaan.
\end{abstract}

Kata Kunci : psikoedukasi, kecerdasan emosional, kecerdasan spiritual 


\section{PENDAHULUAN}

Kecerdasan emosi sangat dibutuhkan manusia, karena akan mendorong untuk berprilaku positif, bijaksana, dan juga memunculkan berbagai macam perasaan, baik senang, sedih, bahagia, sakit dan yang lainnya. Hal yang tidak mungkin bisa dilakukan oleh kecerdasan intelegensi, itulah keuntungan jika memiliki kecerdasan emosional yang baik. Saat ini orangtua dihadapkan pada kondisi yang berat, banyak kasus yang terjadi pada anak-anak, baik sebagai korban maupun sebagai pelaku.

Berdasarkan banyak kasus yang terjadi diketahui bahwa banyak anak yang cerdas secara intelektual, namun melakukan kejahatan, seperti membunuh dengan sadis atau bahkan bunuh diri. Kurangnya kecerdasan emosi serta spiritual pada anak merupakan salah satu faktor banyaknya kasus kekerasan yang terjadi. Di lingkungan sekolah maupun rumahnya, anak hanya dilatih untuk mengembangkan kecerdasan intelektualnya saja. Anak selalu didorong untuk berkompetisi tetapi anak tidak diajarkan untuk bekerja sama, berbagi, mengendalikan emosi, mengenali emosi diri maupun orang lain (Saptoto, 2010). Sehingga dirasa sangat perlu untuk mendampingi masyarakat dalam melatih dan meningkatkan kecerdasan emosional dan spiritual anak melalui psikoedukasi optimalisasi kecerdasan emosi dan spiritual anak sejak dini.

\section{METODE PELAKSANAAN}

Kegiatan dalam program psikoedukasi ini dibagi dua tahap yaitu: (1) tahap sosialisasi dan identifikasi; (2) dan tahap kurikulum belajar. Pada tahap sosialisasi dan identifikasi ini yang dilakukan adalah mengidentifikasi jumlah keluarga yang memiliki anak usia 0-18 tahun, mengidentifikasi karakteristik sosiodemografis para mitra meliputi tingkat pendidikan, pendapatan, karakteristik budaya (bahasa, pola komunikasi, nilai yang dianut), mengidentifikasi masalah yang dihadapi mitra, melakukan koordinasi tim dan mitra terkait. Tujuannya adalah untuk memperkenalkan dan mendiskusikan usulan program edukasi. Pada tahapan ini dilakukan persiapan orang, penyusunan jadwal kegiatan, tempat, media, dan alat bantu. Sedangkan pada tahap kurikulum belajar terbagi dua materi, yaitu psikoedukasi (kecerdasan emosional dan spiritual) dan parenting education (pola asuh dan mengenal kepribadian anak).

\section{HASIL DAN PEMBAHASAN}

Hasil kegiatan Ipteks bagi Masyarakat (IbM) secara garis besar mencakup beberapa komponen sebagai berikut:

(1) Keberhasilan target jumlah peserta penyuluhan

(2) Ketercapaian tujuan pengabdian

(3) Ketercapaian target materi yang disampaikan

(4) Kemampuan peserta dalam penguasaan materi

Target peserta latihan direncanakan sebelumnya adalah minimal 50 orang, dan jumlah peserta yang hadir adalah 100 orang. Dengan demikian target peserta pelatihan dapat dikatakan sukses/berhasil.

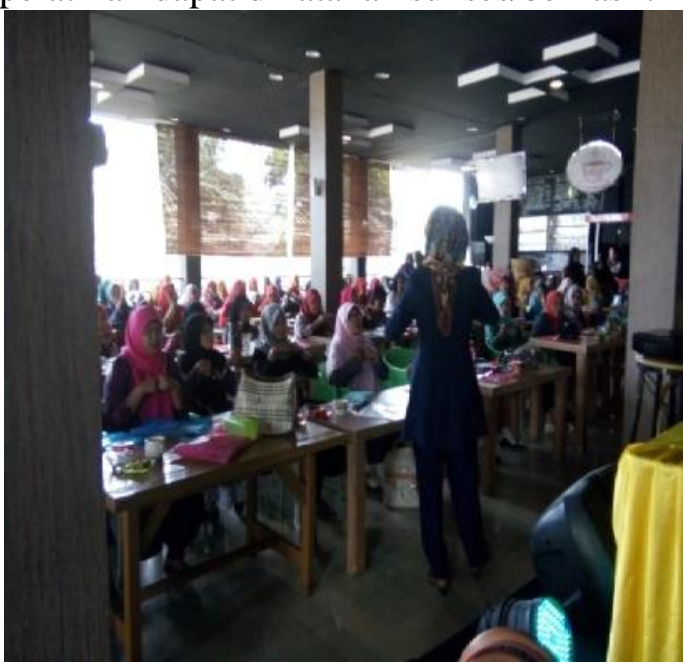

Gambar 1: psikoedukasi kecerdasan emosional 
Ketercapaian tujuan pengabdian secara umum sudah tercapai yaitu guru mampu mengenal dan mengembangkan kecerdasan emosi anak dan guru mampu untuk mengenal potensi serta kepribadian anak.

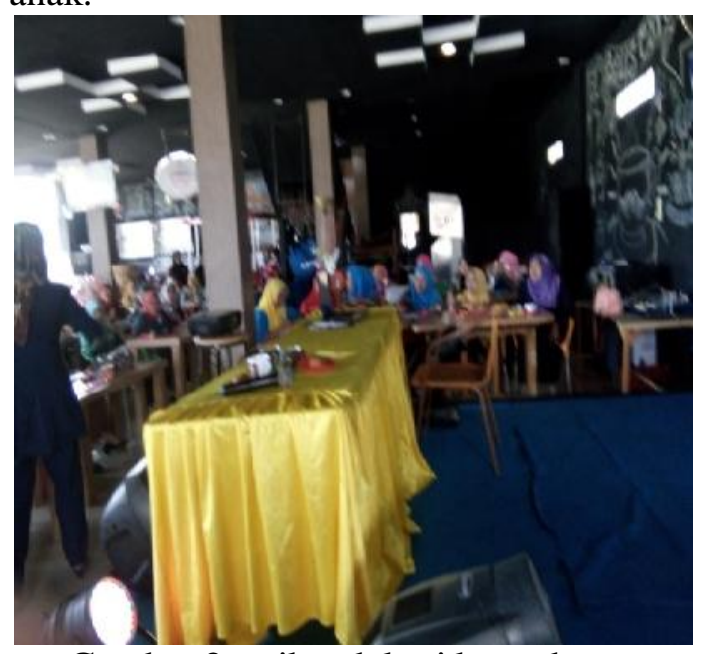

Gambar 2: psikoedukasi kecerdasan spiritual

Materi yang disampaikan juga sudah mencapai target. Semua materi yang telah dirancang sebelum kegiatan dapat disampaikan dengan maksimal. Bahkan waktu yang diberikan untuk sharing dan diskusi mengenai permasalahan anak juga maksimal. Materi yang disampaikan mencakup: (1) mengenal emosi anak, (2) melepaskan emosi negatif, (3) mengelola emosi diri sendiri, (4) memotivasi diri sendiri, (5) mengenali emosi orang lain, (6) memotivasi orang lain, (7) membina hubungan, (8) mengenali kepribadian, dan emosi anak, (9) menerapkan pola asuh yang sesuai dengan perkembangan dan kepribadian anak, (10) berkomunikasi yang baik dengan anak, (11) mendiskusikan segala persoalan bersamasama, (12) menceritakan kisah-kisah yang agung, (13) melibatkan anak dalam ritual keagamaan (Hariastuti, 2007).

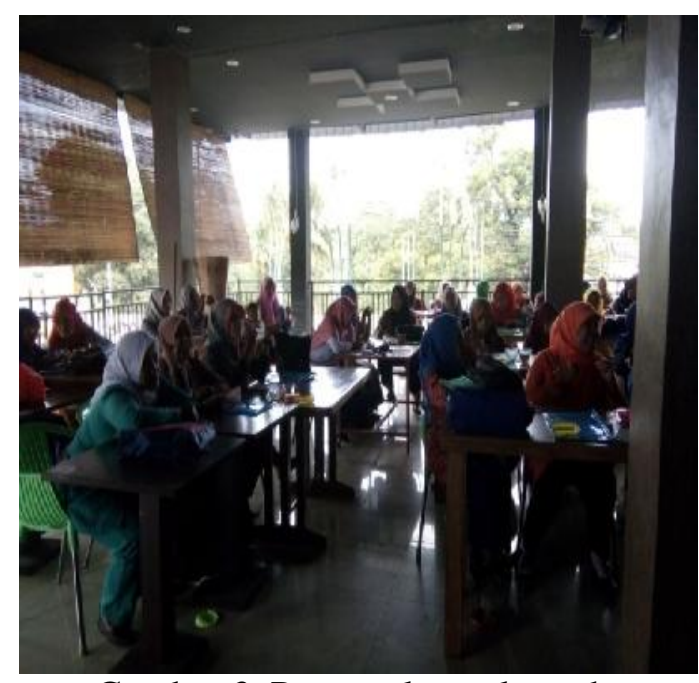

Gambar 3. Pengenalan pola asuh

Penguasaan materi peserta pelatihan diukur melalui tes pemahaman tentang mengoptimalkan kecerdasan emosi dan spiritual anak sejak dini. Nilai rata-rata yang diperoleh dari 100 peserta yaitu 8,6. Sehingga penguasaan materi dapat tercapai.

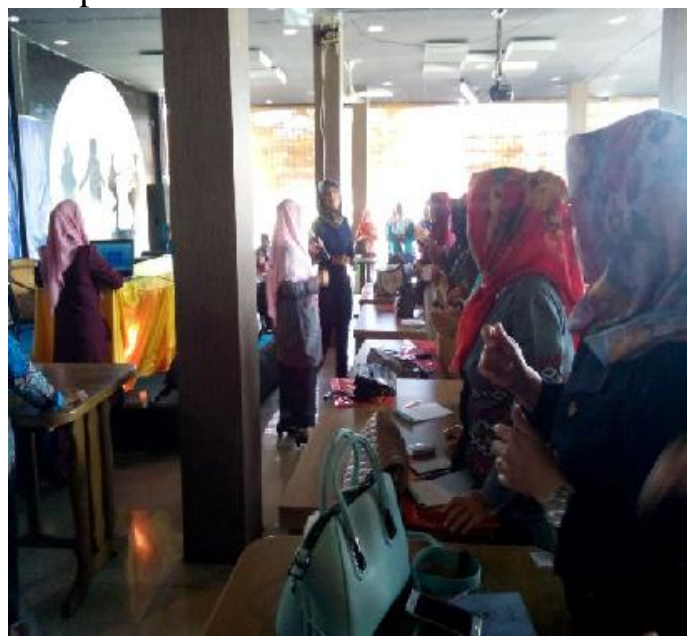

Gambar 4. Praktek pengenalan bakat anak dengan multiple intelligence

\section{SIMPULAN}

Berdasarkan pelatihan optimalisasi kecerdasan emosional dan spiritual anak sejak dini, maka disimpulkan bahwa guru mampu mengenal dan mengembangkan kecerdasan emosi dan spiritual anak melalui bahasa tubuhnya. Materi yang disampaikan mencakup: (1) mengenal emosi anak, (2) melepaskan emosi negatif, 
(3) mengelola emosi diri sendiri, (4) memotivasi diri sendiri, (5) mengenali emosi orang lain, (6) memotivasi orang lain, (7) membina hubungan, (8) mengenali kepribadian, dan emosi anak, (9) menerapkan pola asuh yang sesuai dengan perkembangan dan kepribadian anak, (10) berkomunikasi yang baik dengan anak, (11) mendiskusikan segala persoalan bersama-sama, menceritakan kisah-kisah yang agung, (13) melibatkan anak dalam ritual keagamaan.

\section{UCAPAN TERIMA KASIH}

Pengabdian ini terlaksana dengan bantuan berbagai pihak, terima kasih kepada pihak yang sudah membantu. Sumber dana LPPM UMTS kontrak No.Kept 011/KEP/11.3-AU/F/2017 antara Khairul Amri dan Kepala LPPM Universitas Muhammadiyah Tapanuli Selatan.

\section{DAFTAR PUSTAKA}

Hariastuti, dkk. 2007. Mengembangkan kecerdasan emosional anak. Jurnal pendidikan dasar vol.8, NO.1, 2007: 101-110

$\begin{array}{ccr}\text { Saptoto, } \quad \text { Ridwan. } & 2010 . & \text { Hubungan } \\ \text { Kecerdasan } & \text { Emosi } & \text { dengan } \\ \text { Kemampuan Coping } & \text { Adaptif. } \\ \text { Jurnal psikologi volume } & \text { 37, NO. 1, } \\ \text { JUNI 2010: } 13-22 & \end{array}$

